\title{
PENGARUH VARIASI DOSIS EKSTRAK BATANG BROTOWALI (Trinospora crispa L.) TERHADAP MORTALITAS HAMA KUTU DAUN (Aphis gossypii L.) TANAMAN MENTIMUN (Cucumis sativus L.) SEBAGAI SUMBER BELAJAR BIOLOGI
}

\author{
Yesi $^{1}$ \\ Suharno Zen ${ }^{2}$ \\ Achyani $^{3}$ \\ ${ }^{1,2}$ Program Studi Pendidikan Biologi Universitas Muhammadiyah Metro \\ ${ }^{3}$ Pascasarjana Pendidikan Biologi Universitas Muhammadiyah Metro \\ E-mail: ${ }^{1}$ yesisaja2@gmail.com, ${ }^{2}$ suharnozein@gmail.com, ${ }^{3}$ acysbd@gmail.com
}

\begin{abstract}
The aim of this study was to know the effect of dosage variation brotowali stems extract (Trinospora crispa L.) on the mortality of aphid (Aphis gossypii L.) cucumber (Cucumis sativus L.). The most effective dose for mortality of aphid, and to design of biology learning resources of high school class $x$ even semester in the form of Student Practicum Worksheet (LKPS) . Based on the kruskal wallis test that has been done and shows reject HO that there is an effect if the result X2 count 1273.99> X2 table 19.7 at a 0.05 in the Chi-square table, thus $\mathrm{HO}$ is rejected, and $\mathrm{HI}$ is accepted that there is an influence of variation dose of brotowali (Trinospora crispa L) stem solution to the mortality of aphids (Aphis gossypii L.) cucumber (Cucumis sativus L). The results showed that the most effective dose of brotowali stem extract could result in at $20 \%$ dose. At dose of $20 \%$ there are many compounds from the brotowali stems that can maximize the mortality of aphid pests. The results of the feasibility test learning resources by the validator design and content validators material get good results to be used as a source of biology learning.
\end{abstract}

Kata kunci: Brotowali, kutu daun, mortalitas, mentimun.

\section{PENDAHULUAN}

Tanaman mentimun merupakan komoditas sayuran yang beradaptasi sangat luas, sehingga banyak masyarakat seperti petani menanam tanaman mentimun sebagai sumber perekonomian, karena tanaman mentimun merupakan sumber makanan yang dibudidayakan dan mengandung banyak gizi didalamnya. Mentimun mempunyai prospek yang cerah untuk dibudidayakan karena mentimun dapat dipasarkan di dalam negeri dan diluar negeri. Data Badan Pusat Statistik (2017) bahwa produksi mentimun masih rendah, yaitu rata-rata 10 ton $\mathrm{ha}^{-1}$, hal ini disebabkan karena budidaya mentimun masih dianggap usaha sampingan diantara tanaman budidaya lainnya.
Hama kutu daun (Aphis gossypii L.) adalah merupakan salah satu hama yang menyebabkan produksi tanaman mentimun menurun. Ciri-ciri jenis hama ini yaitu ukuran tubuhnya kecil antara 1-2 $\mathrm{mm}$, berwarna kuning, kemerah-merahan atau hijau gelap sampai hitam. Mengenai gejala yang ditimbulkan dari serangan hama ini yaitu timbulnya bentuk daun yang tidak wajar, seperti keriput atau keriting dan menggulung. Mengingat bahayanya dampak yang bisa ditimbulkan dari serangan hama ini sehingga cara pengendaliannya bisa dilakukan dengan cara menggunakan pestisida nabati, melakukan pergiliran tanaman atau bisa juga dengan cara mengurangi tanaman inang di daerah sekitar kebun mentimun (Rismayani, 2013). 
Hama kutu daun (Aphis gossypii L.) biasanya hidup bergerombol di bawah permukaan daun. Hama ini menyerang dengan cara menusukkan stiletnya pada epidermis daun, buah, dan batang tanaman. Kutu daun betina ukurannya yang berbeda lebih besar, lebar, dan bewarna kuning, sedangkan kutu daun jantan berwarna merah muda. Serangan hama kutu daun dapat menyebabkan daun menguning seperti berkarat, menggulung lalu lama kelamaan daun akan kering dan tanaman akan mati (Zen dkk., 2017).

Berdasarkan hasil pra-survei dan wawancara yang dilakukan dengan petani di Desa Setia Bakti, Kecamatan seputih Banyak didapat bahwa para petani gagal panen mentimun karena tanamannya diserang oleh beberapa hama, salah satunya yaitu hama kutu daun (Aphis gossypii L.). Berdasarkan keadaan tersebut muncul gagasan baru cara yang bisa membuat hama kutu daun berkurang dan mati, dari hal tersebut juga terdapat gambaran baru bahwa tanaman brotowali yang ada disekitar lingkungan para petani tidak digunakan secara maksimal dan jumlahnya sangat banyak. Jadi untuk membuat hama kutu daun berkurang atau mati bisa menggunakan pestisida nabati dari batang brotowali.

Pestisida nabati merupakan pestisida alternatif untuk mengendalikan serangga hama. Pestisida nabati relatif mudah didapat, aman terhadap hewan bukan sasaran, dan mudah terurai di alam sehingga tidak menimbulkan pengaruh samping (Zen dkk., 2017). Pestisida nabati merupakan kearifan lokal di Indonesia yang sangat potensial untuk dimanfaatkan dalam pengendalian Organisme Pengganggu Tanaman (OPT), guna mendukung terciptanya sistem pertanian organik. Secara umum pestisida nabati diartikan sebagai suatu pestisida yang bahan dasarnya berasal dari tumbuhan atau bagian tumbuhan seperti akar, daun, batang atau buah (Ramli, 2013).
Pertumbuhan populasi hama kutu daun dipicu oleh faktor lingkungan, termasuk suhu tinggi dan kelembaban rendah pada musim ketiga (musim kemarau II), serangan hama ini umumnya lebih besar. Waktu tanam tidak serentak dalam satu areal yang luas memicu perkembangan populasinya. Cuaca yang panas mendorong peningkatan populasi hama ini. Pada kondisi panas, siklus hidup hama menjadi lebih pendek yang menyebabkan populasi meningkat. Aplikasi insektisida yang tidak tepat dosis berdampak terhadap musuh alami, resistensi, dan resurgensi. Aplikasi insektisida dengan dosis tinggi memicu timbulnya resistensi hama terhadap insektisida, sedang aplikasi insektisida pada dosis sublethal akan memicu timbulnya resurgensi (Marwoto \& Inayati, 2011).

Tanaman brotowali merupakan tumbuhan liar di hutan, ladang atau ditanam dekat pagar. Biasa ditanam sebagai tumbuhan obat. Menyukai tempat panas, termasuk golongan perdu, memanjat, tinggi batang sampai $2.5 \mathrm{~m}$. Batang sebesar jari kelingking, berbintil rapat, rasanya pahit. Secara umum di dalam tanaman Tinospora crispa terkandung berbagai senyawa kimia, antara lain alkaloid, damar lunak, pati, glikosida, pikroretosid, harsa, zat pahit pikroretin, tinokrisposid, berberin, palmatin, kolumbin dan kaokulin atau pikrotoksin. Tinospora crispa telah banyak digunakan untuk pengobatan. Ekstrak kasar dari Tinospora crispa dapat digunakan sebagai anti inflamasi, anti diabetik, antimalaria, dan analgetik (Malik, 2015). Dosis 5-20\% dalam formulasi larutan (ekstrak) mempunyai toksisitas kontak dan pakan terhadap hama. Pada dosis 5-20\% dalam berbagai formulasi juga dapat menekan populasi hama. Dosis 20\% dapat menyebabkan mortalitas lebih tinggi dari pada dosis 5\% dan 10\% (Saenong, 2016).

Bau khas dari senyawa kimia akan masuk secara ekstraseluler dan kemudian 
ditangkap oleh kemoreseptor pada silia. Molekul bau tersebut selanjutnya akan berikatan dengan OBPs (Odorant-Biding Proteins) dan kemudian dibawa oleh OBPs melewati cairan lymfa di silia menuju olfactory receptor neurons (ORNs) (Borror, 2017).

Mentimun (Cucumis sativus L.) salah satu jenis sayur yang cukup populer di hampir semua negara. Mentimun berasal dari dataran tinggi Himalaya. Mentimun mengandung mineral seperti kalsium, fosfor, kalium, dan besi, serta vitamin A, B, dan C. Kemajuan di bidang teknologi kecantikan mengungkap bahwa mentimun dapat dimanfaatkan sebagai bahan kosmetika untuk perawatan kecantikan dengan diolah menggunakan teknologi modern. Dari sudut pandang ekonomi, mentimun memiliki prospek yang cukup baik, karena diminati di banyak negara (Julisaniah, 2008).

Mortalitas adalah matinya tubuh larva tidak bergerak ketika disentuh, larva tidak melakukan gerakan naik turun bahkan mengapung, dan yang tampak jelas bahwa larva dikatakan sudah mortal yakni kepala larva hampir putus dan tubuhnya mengecil dan berwarna putih pucat. Larva yang tidak mortal masih melakukan gerakan naik turun dan masih aktif artinya jika disentuh bahkan tidak disentuhpun larva tersebut melakukan gerakan naik turun (Sidik, 2015) .

Sumber belajar (learning resource) adalah guru dan bahan-bahan pelajaran baik buku-buku bacaan atau semacamnya. Desain pembelajaran yang biasa disusun guru berupa sumber belajar atau pembelajaran yang umumnya diisi dengan buku-buku rujukan, padahal sumber belajar sesungguhnya tidaklah sesempit dan sesederhana itu (Huzni, 2011). Kebaharuan dalam penelitian ini adalah dapat membuat produk bioinsektisida yang ramah, murah, dan aman terhadap lingkungan yang berasal dari tanaman di sekitar halaman rumah.

\section{METODE}

Penelitian ini merupakan penelitian eksperimen yang menggunakan perlakuan dan pengamatan mortalitas kutu daun pada tanaman mentimun dengan dosis ekstrak batang brotowali yang bervariasi. Metode yang digunakan dalam penelitian ini adalah Rancangan Acak Lengkap (RAL) yang dilakukan dengan kondisi yang seragam atau sama serta dapat terkontrol dari aspek kondisi lingkungan dan media yang harus homogen. Rumus anava non-parametrik 1 jalur digunakan karena data yang telah didapatkan tidak normal dan tidak homogen. Anava non-parametrik 1 jalur ini digunakan untuk menguji adanya perbedaan antara 3 kelompok data atau lebih yang tidak sama yang berasal dari 1 variabel bebas dengan data berbentuk peringkat, rangking atau ordinal dan sebagai asumsi yang kuat bahwa data yang didapatkan berasal dari suatu populasi yang tidak homogen, tidak normal, dan bukan data interval. Dalam penelitian ini perlu adanya langkahlangkah sebagai berikut:

1. Proses Persiapan

Dalam persiapan ini, perlu adanya penyiapan alat dan bahan yang akan digunakan dalam melakukan penelitian.

2. Proses Pembuatan Ekstrak Batang Brotowali

Langkah-langkah dalam pembuatan ekstrak batang brotowali yaitu dalam pembuatan esktrak batang brotowali dilakukan dengan cara maserasi yaitu proses pengekstrakan simplisia menggunakan pelarut dengan beberapa kali pengocokan atau pengadukan pada suhu kamar. Prinsip kerjanya adalah penyaringan zat aktif yang dilakukan dengan cara merendam serbuk simplisia dalam cairan penyaring yang sesuai pada temperatur kamar dan terlindung dari cahaya.

3. Proses Pelaksanaan

Pada tahap pelaksanaan yaitu melakukan percobaan yang akan dilakukan dengan menyiapkan cawan 
petri yang sudah diberi label dan menyiapkan botol penyemprot yang sudah ditentukan dosisnya masingmasing. Mengambil 10 ekor kutu daun dan memasukkan ke dalam cawan petri yang sudah diberikan tanda. Kemudian menyemprotkan ekstrak batang brotowali ke dalam cawan petri sesuai dosisnya yang telah ditentukan, dengan 5 kali penyemprotan dan dengan jarak penyemprotan $30 \mathrm{~cm}$.

\section{Proses Pengamatan}

Pada tahap pengamatan ini adalah mengamati perilaku kutu daun setelah dilakukan penyemprotan. Bila setelah dilakukan penyemprotan terjadi perubahan perilaku kutu daun sampai kutu daun mati, maka proses yang dilakukan berhasil. Hasil pengamatan lalu dicatat sebagai hasil penelitian. Pengamatan dan mencatat hasil penelitian yang dilakukan pada setiap masing-masing perlakuan selama $1 \times 24$ jam dalam 12 kali pengamatan dengan interval waktu 2 jam (Astuti \& Santoso, 2014). Proses pengamatan dilakukan dengan meminta bantuan sebanyak dua orang untuk mengamati proses perilaku kutu daun saat dilakukan penyemprotan ekstrak batang brotowali. Bila dalam tahap pengamatan kutu daun terdapat perubahan perilaku, sampai mati. maka kutu daun dinyatakan telah mengalami mortalitas.

\section{Proses Penghitungan}

Pada tahap perhitungan yaitu melakukan perhitungan dan persentase mortalitas kutu daun dari setiap masingmasing perlakuan yang diberikan yang telah ditentukan. Lama waktu yang dibutuhkan untuk mengetahui mortalitas hama kutu daun yaitu 1x24 jam dalam 12 kali pengamatan dengan interval waktu 2 jam (Astuti \& Santoso, 2014) baru bisa diketahui dan dengan cara mengamati ada atau tidaknya pergerakan hama kutu daun. Hama kutu daun akan berbeda ketika sudah terjadi mortalitas tidak sama dengan perilaku normal seperti pada habitat aslinya yang selalu menempel pada daun, sedangkan yang sudah diberikan semprotan ekstrak batang brotowali kutu daun akan lambat pergerakannya dan hampir tidak ada aktivitas seperti perlakuan normal.

Sumber belajar biologi berupa lembar kerja praktikum siswa pengaruh variasi dosis eskstrak batang brotowali terhadap mortalitas hama kutu daun ini belum ada, oleh sebab itu mencoba merancang produk tersebut untuk proses pembelajaran pada praktikum. Dalam uji produk yang dilakukan hanya sampai uji ahli, dalam uji ahli ini bertujuan untuk memvalidasi lembar kerja praktikum siswa sebagai sumber belajar untuk mempermudah siswa dalam praktikum. Dalam aspek ini yang dinilai dari lembar praktikum yang telah dibuat adalah seperti aspek materi, dan tampilan produk yang dijabarkan.

Berdasarkan aspek-aspek diatas selanjutnya divalidasi dengan menggunakan angket. Angket yang digunakan adalah angket yang mempunyai skala lima poin seperti pada tabel dibawah ini:

Tabel 4. Format Alternatif Angket

\begin{tabular}{c|l|c}
\hline No & Keterangan & Skor \\
\hline 1 & Sangat Sesuai (SS) & 5 \\
\hline 2 & Sesuai (S) & 4 \\
\hline 3 & Kurang Sesuai (KS) & 3 \\
\hline 4 & Tidak Sesuai (TS) & 2 \\
\hline 5 & Sangat Tidak Sesuai (STS) & 1 \\
\hline
\end{tabular}

Sumber: Qurniani (2015)

Data yang diperoleh selanjutnya akan dianalisis dengan berbagai langkahlangkah sebagai berikut:

1. Hasil angket dikuantitatifkan dengan pemberian skor yang sesuai dengan yang telah ditentukan

2. Data dibuat dalam bentuk tabulasi data

3. Presentase dapat dihitung dari tiap-tiap sub variabel dengan menggunakan rumus:

$$
\mathrm{P}(\mathrm{s})=\frac{S}{N} X 100 \%
$$


Keterangan:

$\mathrm{P}(\mathrm{s})$ : Persentase tiap sub variabel

$\mathrm{S} \quad$ : Jumlah skor tiap sub variabel

$\mathrm{N}$ : Jumlah skor maxsimum

4. Berdasarkan persentase yang diperoleh lalu ditransformasikan kedalam tabel. Kriteria kualitatif ditentukan dengan cara sebagai berikut:

a. Ditentukan persentase skor ideal (skor maksimum) = $100 \%$

b. Ditentukan persentase skor terendah (skor minimum) = $0 \%$

c. Range ditentukan dengan = $100-0=100$

d. Interval yang ditentukan $=5$ (sangat baik, baik, cukup baik, tidak baik, dan sangat tidak baik).

e. Lebar interval yang ditentukan )100/5=200).

Berdasarkan penghitungan diatas, maka dapat diketahui range persentase dan kriteria kualitatif, dan dapat dilihat pada tabel dibawah ini.
Tabel 5. Range Persentase dan Kriteria Kualitatif Lembar Kerja Praktikum.

\begin{tabular}{c|l|l}
\hline No & Interval & Kriteria \\
\hline 1 & $\begin{array}{l}81 \%- \\
100 \%\end{array}$ & $\begin{array}{l}\text { Sangat } \\
\text { Baik }\end{array}$ \\
\hline 2 & $61 \%-80 \%$ & Baik \\
\hline 3 & $41 \%-60 \%$ & $\begin{array}{l}\text { Cukup } \\
\text { Baik }\end{array}$ \\
\hline 4 & $21 \%-40 \%$ & $\begin{array}{l}\text { Tidak } \\
\text { Baik }\end{array}$ \\
\hline 5 & $0 \%-20 \%$ & $\begin{array}{l}\text { Sangat } \\
\text { Tidak } \\
\text { Baik }\end{array}$ \\
\hline
\end{tabular}

Sumber: Qurniani (2015)

Lembar kerja praktikum dikatakan valid apabila dari angket diperoleh hasil yang berada pada rentang $81 \%-100 \%$, dan $61 \%-80 \%$ atau pada kriteria "Sangat Baik, dan Baik".

\section{HASIL}

Berdasarkan penelitian yang telah dilakukan, diperoleh tabel mortalitas kutu daun (Aphis gossypii L.) selama 1x24 jam dengan interval waktu 2 jam. Berikut hasil data yang disajikan dengan diagram mortalitas kutu daun (Aphis gossypii L.).

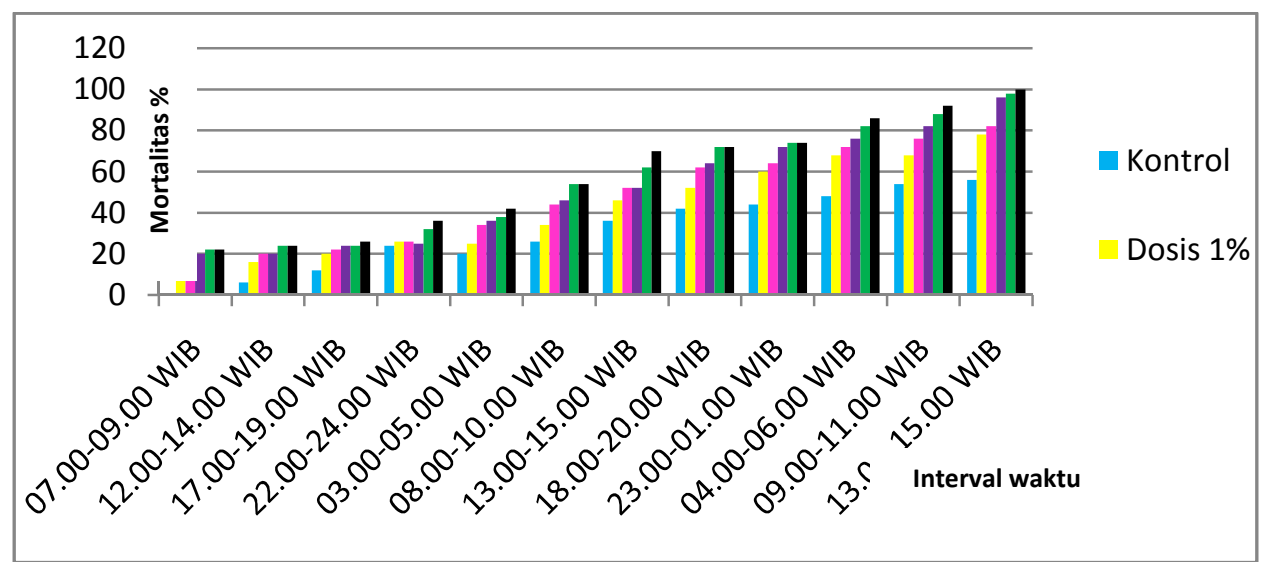

Gambar 5. Diagram hasil pengamatan mortalitas kutu daun (Aphis gossypii L.) selama 1x24 jam dengan interval waktu 2 jam setelah pengamatan.

Berdasarkan diagram pada Gambar 5 dapat dideskripsikan bahwa pada interval waktu 2 jam kedua belas 13.00-15.00 WIB. didapatkan mortalitas tertinggi adalah pada perlakuan keenam yaitu pada dosis ekstrak batang brotowali (Trinospora crispa L) 20\% (dengan nilai mortalitas 100\%). Selanjutnya mortalitas 
terendah dengan dosis kontrol (dengan nilai mortalitas 56\%) dan dosis ekstrak batang brotowali (Trinospora crispa L.) $1 \%$ (dengan nilai mortalitas $30 \%$ ).

Berdasarkan deskripsi di atas didapatkan dari diagram rata-rata mortalitas kutu daun (Aphis gossypii L.) dari jumlah rata-rata tiap interval 2 jam selama 1x24 jam.

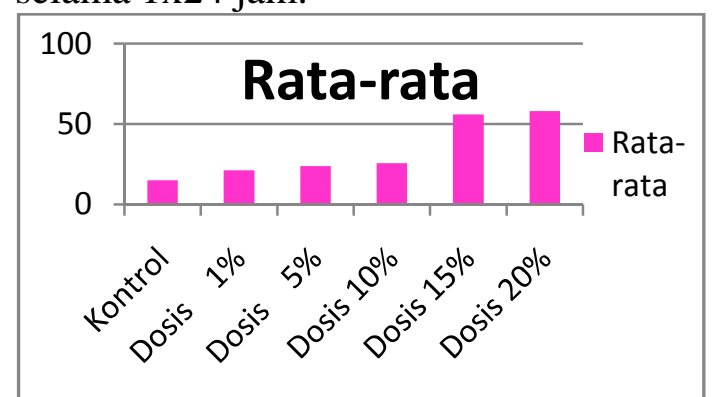

Gambar 6. Diagram rata-rata tiap interval 2 jam selama 1x24 jam terdapat pada lampiran 3.

Berdasarkan Gambar 6 pada perlakuan kontrol rata-ratanya adalah 14,91 dengan nilai terendah $0 \%$ dan nilai tertinggi $28 \%$. Untuk perlakuan dosis ekstrak batang brotowali (Trinospora crispa L) $1 \%$ rata-ratanya adalah 21,33 dengan mortalitas nilai terendah $7 \%$ dan nilai tertinggi 39\%. Untuk perlakuan dosis ekstrak batang brotowali (Trinospora crispa L) 5\% rata-ratanya adalah 23,91 dengan mortalitas nilai terendah $10 \%$ dan nilai tertinggi $41 \%$. Untuk perlakuan dosis ekstrak batang brotowali (Trinospora crispa L) 10\% rata-ratanya adalah 25,27 dengan mortalitas nilai terendah $10 \%$ dan nilai tertinggi $48 \%$. Untuk perlakuan dosis ekstrak batang brotowali (Trinospora crispa L) $15 \%$ rata-ratanya adalah 55,83 dengan mortalitas nilai terendah $22 \%$ dan nilai tertinggi $98 \%$. Untuk perlakuan dosis ekstrak batang brotowali (Trinospora crispa L) $20 \%$ rata-ratanya adalah 58,16 dengan nilai terendah $22 \%$ dan nilai tertinggi $100 \%$.

\section{Tabel Peringkat Analisis Uji Kruskal Wallis}

Berdasarkan hasil analisis uji kruskal wiallis maka didapat peringkat terbesar dari setiap perlakuan X1, X2, X3, X4, X5, dan X6. Berikut tabel diagram hasil analisis uji kruskal wallis:

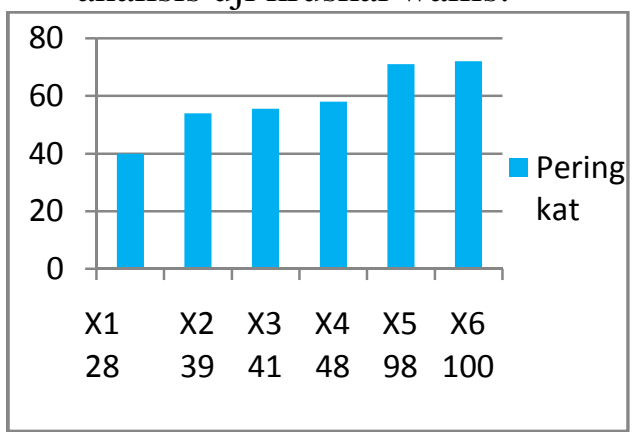

Gambar 7. Diagram Peringkat Hasil Analisis Uji Kruskal Wallis

Berdasarkan Gambar 7 dari hasil analisis uji Kruskal Wallis dapat diketahui bahwa dari setiap perlakuan mempunyai peringkat tertinggi, untuk perlakuan kontrol atau X1 terdapat mortalitas yang sangat tinggi yaitu sebanyak 28 pada waktu pengamatan ke 12 jam 13.0015.00 WIB dengan peringkat 40. Untuk perlakuan dosis $1 \%$ atau $\mathrm{X} 2$ terdapat mortalitas yang sangat tinggi yaitu sebanyak 39 pada waktu pengamatan ke 12 jam 13.00-15.00 WIB dengan peringkat 54. Untuk perlakuan dosis $5 \%$ atau X3 terdapat mortalitas yang sangat tinggi yaitu sebanyak 41 pada waktu pengamatan ke 12 jam 13.00-15.00 WIB dengan peringkat 55,5. Untuk perlakuan dosis $10 \%$ atau $\mathrm{X} 4$ terdapat mortalitas yang sangat tinggi yaitu sebanyak 48 pada waktu pengamatan ke 12 jam 13.0015.00 WIB dengan peringkat 58. Untuk perlakuan dosis $15 \%$ atau X5 terdapat mortalitas yang sangat tinggi yaitu sebanyak 98 pada waktu pengamatan ke 12 jam 13.00-15.00 WIB dengan peringkat 71 . Untuk perlakuan dosis $20 \%$ atau X6 terdapat mortalitas yang sangat tinggi yaitu sebanyak 100 pada waktu 
pengamatan ke 12 jam 13.00-15.00 WIB dengan peringkat 72.

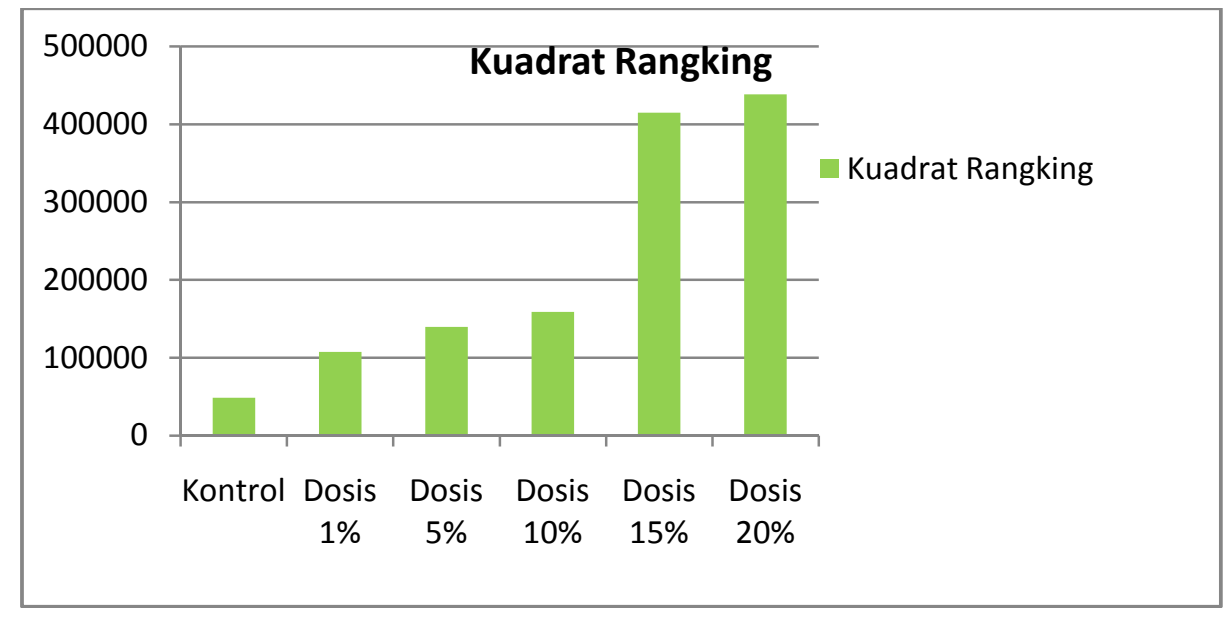

Gambar 8. Diagram Kuadrat Peringkat Hasil Analisis Uji Kruskal Wallis

Berdasarkan uji kruskal wallis yang telah dilakukan dan menunjukkan tolak $\mathrm{H}_{0}$ bahwa terdapat pengaruh jika hasilnya $\mathrm{X}^{2}$ hitung $1273,99>\mathrm{X}^{2}$ tabel 19,7 pada $\alpha 0,05$ pada tabel Chi-square, dengan demikian $\mathrm{H}_{0}$ ditolak, dan $\mathrm{H}_{1}$ diterima bahwa ada pengaruh variasi dosis larutan batang brotowali (Trinospora crispa L) terhadap mortalitas kutu daun (Aphis gossypii L.) tanaman mentimun (Cucumis sativus $\mathrm{L}$ ).

\section{PEMBAHASAN}

Berdasarkan hasil penelitian tentang pengaruh variasi dosis ekstrak batang brotowali (Trinospora crispa L) terhadap mortalitas kutu daun (Aphis gossypii L.) tanaman mentimun (Cucumis sativus L) didapatkan hasil penghitungan menggunakan uji non-parametrik 1 jalur dengan perhitungan uji kruskal wallis 1 jalur didapatkan hasil pada Gambar 5 tentang banyaknya mortalitas kutu daun dan pada gambar 8 terdapat perbedaan mortalitas kutu daun selama 1x24 jam dengan interval waktu 2 jam dengan 6 perlakuan yaitu yang pertama dengan perlakuan kontrol, yang kedua dengan perlakuan dosis $1 \%$, yang ketiga dengan perlakuan dosis 5\%, yang keempat dengan perlakuan dosis $10 \%$, yang kelima dengan perlakuan dosis $15 \%$, dan yang keenam dengan perlakuan dosis $20 \%$.
Berdasarkan hasil penelitian banyaknya mortalitas kutu daun dapat diketahui bahwa mortalitas kutu daun paling sedikit terjadi pada perlakuan kontrol, lalu pada dosis $1 \%$, pada dosis $5 \%$, pada dosis $10 \%$, pada dosis $15 \%$, dan yang terakhir atau yang paling tinggi terdapat mortalitas kutu daun yaitu pada dosis $20 \%$. Jika dilihat dari perlakuan dosis, maka pada dosis $1 \%$ yang merupakan paling sedikit terjadi mortalitas yaitu sebanyak $78 \%$ (39 ekor), dan mortalitas kutu daun yang tertinggi pada dosis $20 \%$ yaitu sebanyak $100 \%$ (50 ekor). Pada dosis $1 \%$ sudah bisa dikatakan efektif, tetapi senyawa-senyawa yang terdapat pada dosis $1 \%$ belum cukup banyak sehingga masih sedikit kutu daun yang mati dibandingkan dengan dosis 20\%. Perlakuan pada dosis $20 \%$ merupakan dosis yang efektif untuk proses mortalitas. Kementan dosis efektif bisa mematikan hewan uji 90-95\%. Pada penelitian ini dosis $20 \%$ dapat mematikan hewan uji sebanyak $100 \%$, sehingga pada penelitian ini pestisida dari batang brotowali termasuk efektif.

Hayne (2014) menyatakan bahwa insektisida masuk ke dalam tubuh serangga dengan berbagai cara, di antaranya sebagai racun kontak yang dapat masuk ke dalam tubuh melalui kulit 
atau dinding tubuh serangga, racun perut atau mulut, masuk melalui alat pencernaan serangga dan yang terakhir dengan fumigan, yang merupakan racun yang masuk melalui pernafasan serangga. Sistem kerja dari racun yang ada di batang brotowali yaitu ketika kutu daun terkena semprotan ekstrak batang brotowali yang terdapat racun-racun maka bau khas senyawa dari batang brotowali tersebut akan masuk secara ekstraseluler dan kemudian ditangkap oleh kemoreseptor pada sensilla di organ pernafasan kutu daun. Molekul bau tersebut selanjutnya akan berikatan dengan OBPs (Odoran binding reseptor) dan kemudian dibawa oleh OBPs melewati cairan lymfa di silia menuju olfactory receptor neurons (ORNs) (Borror, 2017). Selain membawa molekul bau, OBPs juga berfungsi melarutkan molekul bau serta menyeleksi molekul tersebut untuk diterima pada Ors (olfactory reseptor) tertentu. Molekul bau selanjutnya berinteraksi dengan Gprotein couple reseptors ekstraseluler pada ORs yang terletak di dendrit (ORNs) spesifik, dimana secara bergantian G-protein couple reseptors intraseluler aktif dan mengakibatkan perubahan konformasi $G$ protein. Hal tersebut mengakibatkan depolarisasi saraf yang akan memicu terjadinya transmisi impul elektrik ke lobus. menyatakan bahwa molekul bau yang berikatan dengan OBPs tidak selamanya beredar dalam pembuluh limfe, karena akan didegradasi oleh enzim yang dikenal dengan ODES (odordegrading enzymes), dengan kecepatan degradasi tergantung dari molekul yang berikatan dengan OBP tersebut. ODEs berfungsi sebagai regulator, terutama jika molekul bau yang berikatan dengan OBPs berlebihan.

Hasil analisis angket dari ahli desain menghasilkan presentase $80 \%$. Hasil yang didapat ini tergolong ke dalam kategori baik, dengan demikian sumber belajar berupa Lembar Kerja Praktikum Siswa (LKPS) dinyatakan layak untuk dijadikan sebagai Lembar Kerja Praktikum Siswa (LKPS). Hasil analisis angket dari ahli isi materi menghasilkan presentase $78 \%$. Berdasarkan Tabel 5. Hasil yang didapat ini tergolong ke dalam kategori baik, dengan demikian sumber belajar berupa Lembar Kerja Praktikum Siswa (LKPS) dinyatakan layak untuk dijadikan sebagai Lembar Kerja Praktikum Siswa (LKPS).

\section{KESIMPULAN}

Berdasarkan hasil penelitian yang telah dilakukan dapat disimpulkan bahwa terdapat pengaruh variasi dosis ekstrak batang brotowali (Trinospora crispa L) terhadap mortalitas kutu daun (Aphis gossypii L.) tanaman mentimun (Cucumis sativus L). Dosis ekstrak batang brotowali yang paling efektif pada dosis perlakuan $20 \%$ yang mempunyai tingkat mortalitas optimal yaitu mencapai $100 \%$ setelah 1x24 jam dengan interval waktu 2 jam. Hasil penelitian yang dilakukan memiliki kegunaan yang bisa dijadikan sebagai sumber belajar biologi dalam bentuk Lembar Kerja Praktikum Siswa (LKPS).

\section{DAFTAR RUJUKAN}

Astuti, D, dan H. Santoso. 2014. Pengaruh Variasi Dosis Larutan Daun Serai (Andropogon nardus L.) terhadap Mortalitas Larva Nyamuk Aedes sp sebagai Sumber Belajar Biologi. Skripsi tidak diterbitkan. Metro: Universitas Muhammadiyah Metro.

Badan Pusat Statistik. 2017. Tanaman Hortikultura: Tabel Hasil Produksi Tanaman Ketimun Indonesia.https://www.bps.go.id/si te/result. Tab diakses pada tanggal; 2 Noember 2019 pukul 20.00 WIB.

Hayne, KF. 2014. Sublethal effects of neurotoxic insecticides on insect behaviour. Annual Review of Entomology. 33:149-168. 
Huzni, I. S. 2011. Pemanfaatan Media Internet sebagai Sumber Belajar. Jurnal Iqra, 2 (2): 14-20.

Julisaniah, N. I, L. Sulistyowati, \& A. N. Sugiharto. 2008. Analisis Kekerabatan Mentimun (Cucumis sativus L.) Menggunakan Metode RAPD-OCR dan Isozim. Jurnal Biodiversita, 9 (2): $16-22$.

Malik, M. M. 2015. The Potential Of Brotowali Stem Extract (Tinospora crispa) As Analternative Antimalarial Drug. Jurnal J Majority, 4 (5): 2 - 8.

Marwoto, dan A. Inayati. 2011. Kutu Kebul: Hama Kedelai yang Pengendaliannya Kurang Mendapat Perhatian. Jurnal Iptek Tanaman Pangan. 6 (1): 26 - 30.

Qurniani, A. 2015. Pemberian Variasi Dosis Pupuk Cair LCN (Limbah Cair Nanas) terhadap Pertumbuhan Tanaman Anggrek Dedrobium sp untuk Menyusun Rancangan Panduan Praktikum Materi Pertumbuhan dan Perkembangan. Skripsi Tidak diterbitkan. Metro. Universitas Muhammadiyah Metro.

Ramli, dan N. Sumarnina. 2013. Efektifitas Aplikasi Pestisida Nabati terhadap Hama Walang Sangit (Leptotocorisa oratorius) pada Tanaman Padi (Oryza sativa) Di Kelompok Tani "Mandiri" Desa Cipeuyeum Kecamatan
Haur Wangi Kabupaten Cianjur. Jurnal Agroscience, 6 (1): 11 - 17. Rismayani, R. 2013. Dinamika populasi kutu tempurung (Coccus viridis) dan kutu daun (Aphis gossypii L.) pada tiga varietas kopi arabika (Coffea arabica). Jurnal Littri, 19 (4): 159-166.

Saenong, M. Sudjak. 2016. Tumbuhan Indonesia Potensial sebagai Insektisida Nabati untuk Mengendalikan Hama Kumbang Bubuk Jagung (Sitophilus spp.). Jurnal Litbang Pertanian, 35 (3): $5-11$.

Sidik, B. R. 2015. Pengaruh Variasi Dosis Larutan Buah Belimbing Wuluh (Averrhoa bilimbi L.)Terhadap Mortalitas Larva Nyamuk Culex Sp. Sebagai Sumber Belajar Biologi Pada Materi Insekta. Jurnal Pendidikan Bioedukasi, 6 (2): 105 - 111.

Zen, S, dan R. Noor. 2017. Inventarisasi Tanaman yang Berpotensi sebagai Bioinsektisida Nyamuk Aedes aegyptii di Kota Metro Provinsi Lampung. Jurnal Pendidikan Biologi. 7(2): 139-142.

Zen, S, dan T. Asih. 2017. Potensi Ekstrak Bunga Tahi Kotok (Tagetes erecta) sebagai Repellent terhadap Nyamuk Aedes aegypti Yang Aman dan Ramah Lingkungan. Jurnal Pendidikan Biologi. $\quad 8(2): \quad$ 142-149. 